\title{
Headaches and polygenic scores
}

Bjarni J. Vilhjálmsson, PhD, and Florian Privé, PhD

Neurol Genet 2019;5:e368. doi:10.1212/NXG.0000000000000368

Correspondence

Dr. Vilhjálmsson

bjv@econ.au.dk

\section{RELATED ARTICLE}

Polygenic risk scores are en vogue. This ubiquitous statistic quantifies disease liability for an individual by aggregating risk contributions from a large number of genetic variants into a single score. Recent publications have argued that risk models currently used in clinical settings for coronary artery disease can be improved by including polygenic risk scores. ${ }^{1,2}$ Similarly, polygenic risk scores have shown promise in improving breast cancer risk prediction ${ }^{3}$ and are already routinely used by direct-to-consumer genetic testing companies, such as $23 \mathrm{andMe}$, to estimate disease risk. Now, in this issue of Neurology ${ }^{\circledR}$ Genetics, Kogelman et al. ${ }^{4}$ find that the polygenic risk score for migraine, a common headache disorder that is thought to affect about $18 \%$ of the population $^{5}$ and estimated to be quite heritable (between $34 \%$ and $57 \%$ ), ${ }^{6}$ correlates with triptans treatment response when treating migraine. However, there is no reason for people having migraines to rush and get genotyped. First, the treatment response effect was found to be small (but significant). Second, although Kogelman et al. accounted for population structure in their statistical analysis, it is hard to rule out other sources of confounding. Third, it is very difficult to estimate population risk, or conditional risk, as the sample used in this study (and most other studies) is of course ascertained (nonrandom sample). Fourth, if in doubt about the treatment response, why not try the drug?

Even without a clear case for using genetic testing and polygenic scores when treating migraine, the work by Kogelman et al. ${ }^{4}$ and others ${ }^{7}$ provides a strong argument for more research on whether polygenic scores can predict treatment response and to what extent. This is of course not a new suggestion. ${ }^{8}$ This is what pharmacogenomics is about-namely, studying the genetics of drug responses. Indeed, genetic testing for drug responses is already routinely used in clinical settings when prescribing specific drugs. ${ }^{9}$ It is therefore not hard to imagine that polygenic scores, which can be viewed as a genetic test that includes more than 1 genetic variant, can improve drug response predictions. To illustrate this further, let us imagine a polygenic disease with 2 common subtypes for which the genetic architecture is different. If a drug is only effective in treating the first subtype, a polygenic prediction distinguishing between the 2 would of course also predict the drug response. How common such examples are in practice of course remains to be seen.

\section{Toward a data-driven prediction approach}

Risk prediction is common in clinical settings. For example, most pregnant women currently undergo an ultrasound to measure nuchal fold thickness, which (together with other risk factors) is used in many countries to screen for chromosomal abnormalities. Similarly, genetic variants, metabolites in blood, age, body mass index, and other individual-level data may tell a story for other diseases and disorders. The challenge is to identify what clinically relevant questions are we interested in answering, and which ones can we answer with the available data, including genetic data. As genetic data sets continue to grow rapidly, we expect them to become more relevant in clinical settings.

When considering applying polygenic scores in clinical settings, it is important that it rigorously validated in terms of accuracy and how useful it is. ${ }^{10}$ First, the validation sample

\section{Article}

Migraine polygenic risk score associates with efficacy of migraine-specific drugs

Page e364 
should be fully independent (from the training sample). Second, biases due to population structure or other confounders should be accounted for. Third, the validation sample must represent the population or subpopulation on which it will be applied and be large enough to report meaningful accuracies. Fourth, it is important that any proposed model is benchmarked against current practices and models currently used. This includes examining relative gains in prediction accuracy compared with currently used approaches. This is especially important if the aim is to use it in clinical settings. Finally, clinical relevance and value should be considered carefully, as genetic screening comes with a cost, both economical and sometimes a significant psychological cost that can easily outweigh benefits.

\section{Author contributions}

B.J. Vilhjálmsson/F. Privé: drafting/revising the manuscript.

\section{Study funding}

No targeted funding reported.

\section{Disclosure}

The authors report no disclosures. Disclosures available: Neurology.org/NG.

\section{References}

1. Khera AV, Chaffin M, Aragam KG, et al. Genome-wide polygenic scores for common diseases identify individuals with risk equivalent to monogenic mutations. Nat Genet 2018;50;1219-1224.

2. Inouye $\mathrm{M}, \mathrm{Abraham} \mathrm{G}, \mathrm{Nelson} \mathrm{CP}$, et al. Genomic risk prediction of coronary artery disease in 480,000 adults: implications for primary prevention. J Am Coll Cardiol 2018;72:1883-1893.

3. Lee A, Mavaddat N, Wilcox AN, et al. Correction: BOADICEA: a comprehensive breast cancer risk prediction model incorporating genetic and nongenetic risk factors. Genet Med 2019;21:1462.

4. Kogelman LJA, Esserlind A-L, Francke Christensen A, et al. Migraine polygenic risk score associates with efficacy of migraine-specific drugs. Neurol Genet 2019;5:e364 doi:10.1212/NXG.0000000000000364.

5. Mokdad AH, Forouzanfar MH, Daoud F, et al. Global burden of diseases, injuries, and risk factors for young people's health during 1990-2013: a systematic analysis for the Global Burden of Disease Study 2013. Lancet 2016;387:2383-2401.

6. Mulder EJ, Van Baal C, Gaist D, et al. Genetic and environmental influences on migraine: a twin study across six countries. Twin Res 2003;6:422-431.

7. Christensen AF, Esserlind AL, Werge T, Stefánsson H, Stefánsson K, Olesen J. The influence of genetic constitution on migraine drug responses. Cephalalgia 2016;36:624-639.

8. Gibson G. On the utilization of polygenic risk scores for therapeutic targeting. Plos Genet 2019;15:e1008060.

9. Nelson MR, Johnson T, Warren L, et al. The genetics of drug efficacy: opportunities and challenges. Nat Rev Genet 2016;17:197-206.

10. Wray NR, Yang J, Hayes BJ, Price AL, Goddard ME, Visscher PM. Pitfalls of predicting complex traits from SNPs. Nat Rev Genet 2013;14:507-515. 


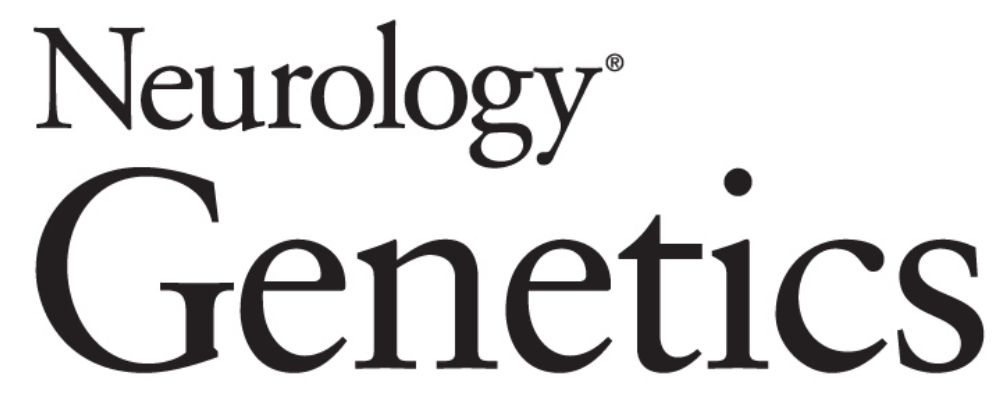

Headaches and polygenic scores

Bjarni J. Vilhjálmsson and Florian Privé Neurol Genet 2019;5;

DOI 10.1212/NXG.0000000000000368

This information is current as of October 24, 2019

\section{Updated Information \&} Services

References

Permissions \& Licensing

Reprints including high resolution figures, can be found at: http://ng.neurology.org/content/5/6/e368.full.html

This article cites 10 articles, 2 of which you can access for free at: http://ng.neurology.org/content/5/6/e368.full.html\#\#ref-list-1

Information about reproducing this article in parts (figures,tables) or in its entirety can be found online at:

http://ng.neurology.org/misc/about.xhtml\#permissions

Information about ordering reprints can be found online: http://ng.neurology.org/misc/addir.xhtml\#reprintsus

Neurol Genet is an official journal of the American Academy of Neurology. Published since April 2015, it is an open-access, online-only, continuous publication journal. Copyright Copyright () 2019 The Author(s). Published by Wolters Kluwer Health, Inc. on behalf of the American Academy of Neurology.. All rights reserved. Online ISSN: 2376-7839.

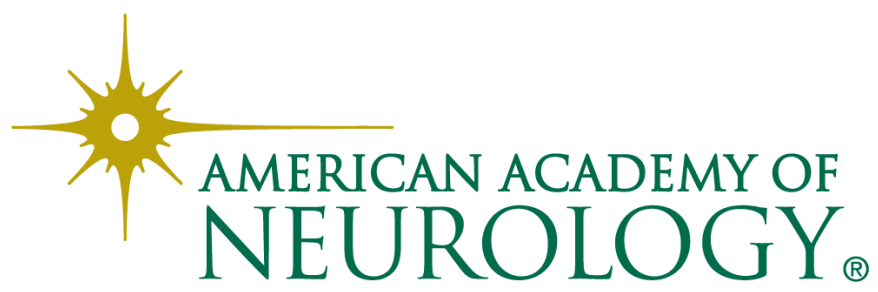

